\section{Row Width, Population Density, and Harvest Date Effects on Marketable Yield of Table Beet}

\author{
Julie R. Kikkert ${ }^{1,5}$, Stephen Reiners ${ }^{2}$, and Beth K. Gugino ${ }^{3,4}$
}

AdDitional InDEX wORDs. Beta vulgaris, root size, stand establishment, plant spacing

SumMary. To maximize the yield of desirable grades of beet roots for processing, 'Ruby Queen' beet (Beta vulgaris) plants were grown at four row widths $(18,20$, 22 , and 24 inches) and two population densities (25 and 35 plants $/ \mathrm{ft}$ ) within the row in 2006. A third density (15 plants/ft) was added to the 18 - and 20 -inch row-width treatments in 2007. Beet plants were hand harvested 80, 100, and 120 days after planting, and the roots were graded by size and were weighed. A large number of seedlings died between the time of the initial stand counts 14 to 20 days after planting and the first harvest. Greater seedling loss at higher plant densities within rows was attributed in part to an increased incidence of wirestem disease (Rbizoctonia solani). The percentage of seedlings that produced marketable roots was less at higher seeding rates even though there were more total roots. Harvest date and plant population significantly affected root size and yield, whereas row width had no effect. High seeding rates and fewer days to harvest significantly increased the yield of undersize $(<3 / 4$ inches in diameter) roots, while at the same time decreased the yield of oversize roots $(>21 / 2$ inches in diameter). The highest yield of premium size 1 roots $(3 / 4$ inch to $<15 / 8$ inches in diameter) was obtained with the 35 plants/ft population. While the number of size 1 roots did not increase over the harvest period, the fresh weight per foot of row was significantly higher at 100 or 120 days compared with 80 days. In contrast, the number and fresh weight of larger size 2 roots $(15 / 8$ to $<21 / 2$ inches in diameter)/ft of row was highest at 25 plants/ft and did increase with number of days to harvest. The highest marketable yield (sizes 1 and 2 roots) increased significantly with number of days to harvest and was 1.6 to 1.8 tons/acre higher with 25 plants/ft compared with 35 plants/ft. High seeding rates and narrower row spacing increased the cost of seeds per acre and the risk for wirestem and other beet diseases, but did not improve yields in this study.

$\mathrm{T}$ able beet is a specialty crop in Europe, North America, Australia, and parts of Asia (Goldman and Navazio, 2008). In the United States, table beet is grown on 8412 acres, with 5275 acres harvested for processing (USDA, 2009). Wisconsin and New York account for more than $90 \%$ of the processing acreage. Table beet roots for canning are graded by size after harvest based on

This research was supported by the New York Vegetable Research Association.

We thank Jim Ballerstein for assistance with the field trials, and Francoise Vermeylen, Cornell University Statistical Consulting Unit, for assistance with data analysis.

${ }^{1}$ Cornell University Cooperative Extension Regional Vegetable Program, 480 North Main Street, Canandaigua, NY 14424

${ }^{2}$ Department of Horticultural Sciences, Cornell University, New York State Agricultural Experiment Station, 630 West North Street, Geneva, NY 14456

${ }^{3}$ Department of Plant Pathology, Cornell University, New York State Agricultural Experiment Station, 630 West North Street, Geneva, NY 14456

${ }^{4}$ Current address: Department of Plant Pathology, The Pennsylvania State University, 219 Buckhout Laboratory, University Park, PA 16802

${ }^{5}$ Corresponding author. E-mail: jrk2@cornell.edu. the needs of the processor. Growers are paid for the tons of each grade delivered. Currently in New York, roots $3 / 4$ to $<13 / 4$ inches in diameter are twice the value per ton of those $21 / 2$ to 3 inches in diameter. Additionally, processors will only accept $10 \%$ of roots $21 / 2$ to 3 inches in diameter, and none larger than 3 inches. Further grading at the plant is based on tenderness, uniformity, color, and freedom from defects (USDA, 1998).

Uniformity of beet roots is difficult to obtain in growers fields. Standard globe-shaped processing varieties continue to increase in diameter as long as they are in the ground, have sufficient space to grow, and receive adequate water and nutrients (Hipp, 1977; Warne, 1953). Most varieties have multigerm seedballs, and emergence takes place over a prolonged period, depending on environmental conditions. Benjamin (1987) reported seedling emergence in the multigerm variety Boltardy over a range of 12 to $32 \mathrm{~d}$ in one experiment and 5 to $21 \mathrm{~d}$ in a second experiment. The time of seedling emergence was a major source of variation in the size of roots at harvest. When seedlings of uniform size were selected 3 to 4 weeks after emergence, the yield of marketable grade beets increased (Benjamin and Bell, 1985). In the field, uneven moisture, soil crusting, and diseases can reduce and cause unevenness in stands. To overcome these factors, growers typically use high seeding rates.

It is well documented that higher plant densities within the row increase the proportion of plants with small roots, usually at the expense of total beet yield (Benjamin et al., 1985; Mack, 1968, 1979; Peck and Wilczynski, 1967; Tyler et al., 1982; Warne, 1948; Webster, 1969). Tyler et al. (1982) found that the yield of "baby beets" (1.0-1.7 inches diameter) peaked at a density of 183 plants / $\mathrm{m}^{2}\left(17.0\right.$ plants $\left./ \mathrm{ft}^{2}\right)$ and decreased at higher population densities.

The effect of between-row spacing on the yield of different grades of beet roots is less clear. Mack (1968) reported that the percentage of beets between 1 and 2 inches in diameter increased from $6 \%$ to $44 \%$ when the row spacing was reduced from 24 to 6 inches. Similarly, the yield of beet roots 1 to $13 / 4$ in inches diameter was 38\% higher with 9 -inch rows compared with 24-inch rows (Peck and Wilczynski, 1967). Mack (1979) compared 6-, 12-, 18-, and 24-inch rows combined with three seeding rates. There was no interaction of

\begin{tabular}{lllc}
\hline $\begin{array}{l}\text { Units } \\
\begin{array}{l}\text { To convert U.S. to SI, } \\
\text { multiply by }\end{array}\end{array}$ & U.S. unit & SI unit & $\begin{array}{l}\text { To convert SI to U.S., } \\
\text { multiply by }\end{array}$ \\
\hline 0.4047 & $\mathrm{acre}(\mathrm{s})$ & $\mathrm{ha}$ & 2.4711 \\
0.3048 & $\mathrm{ft}$ & $\mathrm{m}$ & 3.2808 \\
0.0929 & $\mathrm{ft}^{2}$ & $\mathrm{~m}^{2}$ & 10.7639 \\
2.54 & inch(es) & $\mathrm{cm}$ & 0.3937 \\
0.4536 & $\mathrm{lb}$ & $\mathrm{kg}$ & 2.2046 \\
1.1209 & $\mathrm{lb} / \mathrm{acre}$ & $\mathrm{kg} \cdot \mathrm{ha}^{-1}$ & 0.8922 \\
1.4882 & $\mathrm{lb} / \mathrm{ft}$ & $\mathrm{kg} \cdot \mathrm{m}^{-1}$ & 0.6720 \\
2.2417 & ton/acre & $\mathrm{Mg} \cdot \mathrm{ha}^{-1}$ & 0.4461
\end{tabular}


row spacing and within-row seeding rate on yields. As row spacing decreased, yields of roots in the sizes $<\mathrm{l}$ inch and 1 to 2 inches in diameter increased, while yields of larger size and total beet roots decreased. Similar results were obtained in another experiment where seeding rate was held constant (Mack, 1979). However, Benjamin et al. (1985), in a series of experiments where eight row widths between 4 and 20 inches and several plant densities were tested, reported that row width had no effect on total root yield or grade, except when the crop was harvested early. In comparing these reports, first, one must be careful to note whether data were presented as percentage of total roots or weight per unit area because there are more rows and hence more plants per unit area as the row widths decrease. Second, in-row density must also be considered. Warne (1948) concluded that maximum yields were based on total plants per unit area, and not on a particular spatial arrangement. Furthermore, minor differences in plant stand were of less importance when the rows were closely spaced.

Peck and Wilczynski (1967) reported that the yield of small beet roots ( 1 to $13 / 4$ inches in diameter) remained nearly constant over six harvest dates from 69 to $114 \mathrm{~d}$ after planting, whereas the yield of medium and large roots increased over time. Similarly, Mack (1979) found that the yield of beet roots less than $l$ inch in diameter was not influenced by harvest dates in the range of 73 to $107 \mathrm{~d}$, but was significantly less at $57 \mathrm{~d}$. The yield of larger roots was significantly higher as harvest date increased. There was also a significant interaction of harvest date and row spacing. Hipp (1977) reported differences in the size distribution of beet roots based on harvest date and nitrogen application.

New York growers typically grow beets at 35 plants/ft in-row spacing and 22 or 24 inches between rows. However, they remain frustrated by the number of large beet roots $(>21 / 2$ inches in diameter) that often appear at harvest. The abundance of oversized beet roots is likely due to sections of rows where plants are widely spaced due to irregular germination and emergence or loss of seedlings (Warne 1948). In 1967, Peck and
Wilczynski demonstrated that beet plants grown in 9-inch rows instead of 24-inch rows produced more small ( 1 to $<13 / 4$ inches in diameter) and medium ( $13 / 4$ to $21 / 2$ inches in diameter) roots, resulting in a $\$ 100 /$ acre higher value. However, growers in New York have not adopted this practice because narrow rows are impractical with cultivation and harvesting equipment currently used for commercial beet production.

This study was initiated to determine the combination of row width, within-row plant density, and harvest date that will yield the highest weight of marketable beet roots using only row widths that were possible with current field equipment.

\section{Materials and methods}

Field trials. 'Ruby Queen' table beet was planted at the Cornell University Vegetable Research Farm in Geneva, NY, in 2006 and 2007 where the soil type was Lima Silt Loam. Seedballs were treated commercially with mefenoxam fungicide (Apron XL; Syngenta Crop Protection, Greensboro, NC) and tetramethylthiuram disulfide fungicide (42-S Thiram; Bayer Crop Science, Research Triangle Park, NC) in 2006 and mefenoxam, tetramethylthiuram disulfide, and fludioxonil fungicide (Maxim 4FS; Syngenta Crop Protection) in 2007. Beet seedballs were planted in strips of three rows. A vacuum planter (Monosem, Lenexa, KS) was used to sow the middle and one outside row, while the other outside row was hand planted. This was due to technical constraints of the tractor and planting unit.

Before planting, $300 \mathrm{lb} /$ acre of $15 \mathrm{~N}-6.5 \mathrm{P}-12.5 \mathrm{~K}$ fertilizer was broadcast and incorporated into the soil. Pyramin herbicide (Pyrazon; Arysta

Table 1. The effect of seeding rate on the initial plant stand 14 to $20 \mathrm{~d}$ after planting, and the survival of 'Ruby Queen' table beet plants $80 \mathrm{~d}$ after planting in field plots in 2006 and 2007.

\begin{tabular}{|c|c|c|c|c|}
\hline $\begin{array}{l}\text { Target population } \\
(\text { plants } / \mathrm{ft})^{\mathrm{z}}\end{array}$ & 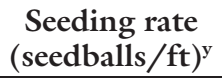 & $\begin{array}{l}\text { Initial stand } \\
{\text { (plants } / \mathrm{ft})^{\mathrm{x}}}^{\text {plant }}\end{array}$ & $\begin{array}{c}\text { Roots at } 80 \mathrm{~d} \\
(\text { no. } / \mathrm{ft})^{\mathrm{w}}\end{array}$ & $\begin{array}{c}\text { Plant loss at } \\
80 \mathrm{~d}(\%) \\
\end{array}$ \\
\hline \multicolumn{5}{|l|}{2006} \\
\hline 25 & 18 & $25.6 \mathrm{~b}^{\mathrm{v}}$ & $19.5 \mathrm{~b}$ & $23.8 \mathrm{~b}$ \\
\hline 35 & 26 & 35.9 a & $23.8 \mathrm{a}$ & $33.1 \mathrm{a}$ \\
\hline \multicolumn{5}{|l|}{2007} \\
\hline 15 & 11 & $15.9 \mathrm{c}$ & $14.4 \mathrm{c}$ & $11.5 \mathrm{c}$ \\
\hline 25 & 18 & $21.6 \mathrm{~b}$ & $17.6 \mathrm{~b}$ & 17.7 b \\
\hline 35 & 26 & $29.7 \mathrm{a}$ & $22.1 \mathrm{a}$ & $24.4 \mathrm{a}$ \\
\hline
\end{tabular}

${ }^{{ }^{2}}$ Target population is the desired number of plants per foot of row; 1 plant $/ \mathrm{ft}=3.2808$ plants $/ \mathrm{m}$. Because 'Ruby Queen' table beet seedballs are multigerm, the target population was calculated based on the average number of seedlings/seedball in germination tests. A field factor of 0.8 was used because seedballs planted in field conditions produce an average of $80 \%$ fewer seedlings in New York soils than in laboratory tests.

${ }^{y}$ Actual number of seedballs planted per foot of row; 1 seedball $/ \mathrm{ft}=3.2808$ seedballs $/ \mathrm{m}$.

${ }^{x}$ Emerged seedlings were counted at $14 \mathrm{~d}$ after planting in 2006 and $20 \mathrm{~d}$ after planting in 2007 . Emergence was delayed in 2007 because of drought.

"Mean number of roots per foot at harvest which began $80 \mathrm{~d}$ after planting; $1 \mathrm{root} / \mathrm{ft}=3.2808$ roots $/ \mathrm{m}$. Because harvest date $(80,100$, and $120 \mathrm{~d}$ after planting) was not significant, the data were combined.

${ }^{\mathrm{v}}$ Means within a year in each column that are followed by the same letter are not significantly different at $P=0.05$ as determined by Student's $t$ tests in 2006 and Tukey's honestly significant differences tests in 2007.

Table 2. Effect of planting density on the percentage of table beet seedlings with wirestem disease. Commercial lots of 'Ruby Queen' and 'Red Ace' table beet seedballs were sown in soil collected from a beet field and were grown in the greenhouse for $36 \mathrm{~d}$. Seedballs were treated commercially with fungicides that inhibit the growth of the multiple organisms that cause wirestem. There was no difference in cultivar or seed lot, and only the combined data are presented.

\begin{tabular}{|c|c|c|c|}
\hline $\begin{array}{l}\text { Seedball density } \\
(\text { no. } / 4 \text { inches })^{\mathrm{z}}\end{array}$ & $\begin{array}{l}\text { Stand at } 36 \mathrm{~d} \\
\text { (no. plants) }\end{array}$ & $\begin{array}{l}\text { Mean seedlings at } \\
36 \mathrm{~d} \text { (no./seedball) }\end{array}$ & $\begin{array}{c}\text { Seedlings with } \\
\text { wirestem at } 36 \mathrm{~d}(\%)\end{array}$ \\
\hline 5 & $8.7 c^{y}$ & $1.7 \mathrm{a}$ & $0.6 \mathrm{c}$ \\
\hline 10 & $17.5 \mathrm{~b}$ & $1.7 \mathrm{a}$ & $12.9 \mathrm{~b}$ \\
\hline 15 & $25.9 \mathrm{a}$ & $1.7 \mathrm{a}$ & $34.5 \mathrm{a}$ \\
\hline
\end{tabular}

${ }^{\mathrm{z}} \mathrm{A}$ total of 5,10 , or 15 seedballs were planted in a single row in a 4 -inch-diameter $(10.2 \mathrm{~cm})$ pot; 1 seedball/ 4 inches $=0.0984$ seedball $/ \mathrm{cm}$.

${ }^{y}$ Means within each column followed by the same letter are not significantly different at $P=0.05$ as determined by Tukey's honestly significant differences tests. 
Lifescience North America, Cary, NC) was applied after planting and 0.5 inches of water was applied the next day. The plants were sidedressed with $80 \mathrm{lb} /$ acre nitrogen 3 weeks after planting. Plants were irrigated in 2007 when necessary. There was no irrigation in 2006.

Four row widths, 18, 20, 22, and 24 inches, were tested each year. In 2006, beet seedballs were planted at 18 or 26 seedballs/ft in each of the three rows per plot to achieve the target plant populations of 25 and 35 plants/ft. There were eight planting treatments representing all combinations of the row widths and in-row populations. The trial was repeated in 2007, with the addition of a third seeding rate of $\mathrm{ll}$ seeds/ $\mathrm{ft}$ for a target population of 15 plants $/ \mathrm{ft}$ in the 18 and 20 -inch row widths only. There were a total of 10 planting treatments in 2007.

A split-plot design with four replicate subplots for each combination of row width and plant population was used. In 2006, the field was divided into two blocks. Each block contained four plots; each plot represented one of the four row widths tested. The plots were three rows wide and a total of $95 \mathrm{ft}$ in length, and consisted of four 20 -ft-long subplots and three 5-ft-long unplanted sections between the subplots. The subplots represented the target plant populations ( 25 or 35 plants/ft). After the majority of the seedlings emerged (14 d after planting in 2006), six 2-ft-long sections of the center row in each subplot were selected that appeared to have a good stand. These sections were permanently marked off with stakes and the number of seedlings $/ 2 \mathrm{ft}$ of row was nondestructively counted. Plants from two of the 2-ft-long sections of rows in each subplot were hand harvested at 80,100 , and $120 \mathrm{~d}$ after planting. The experimental design for 2007 was similar to 2006 ; however, due to the additional treatments, there were three plots for each of the 18- and 20-inch row widths and two plots each for the 22- and 24-inch row widths. The total length of the plots was $115 \mathrm{ft}$ and each consisted of four 25 -ft-long subplots with $5 \mathrm{ft}$ unplanted between subplots. The plots were randomly planted and the field was considered one block. In 2007 , stand counts were taken at $20 \mathrm{~d}$


Fig. 1. The effect of in-row plant population and harvest date on the number of 'Ruby Queen' table beet roots in different size classes from 2006 and 2007 field plots; size 0 ( $<3 / 4$ inch diameter), size 1 ( $3 / 4$ to $<15 / 8$ inches diameter $)$, size 2 ( $15 / 8$ to $<21 / 2$ inches diameter), and size $3(>21 / 2$ inches diameter). Vertical bars represent $\mathrm{SE} ; 1$ inch $=2.54 \mathrm{~cm}, 1$ root $/ 2 \mathrm{ft}=1.6404$ roots $/ \mathrm{m}, 1$ plant $/ \mathrm{ft}=3.2808$ plants $/ \mathrm{m}$.

because emergence was delayed due to dry conditions that prevailed despite irrigation.

At each harvest, the total number of plants pulled from each 2 -ft-long row section was recorded. Tops were twisted off of the roots. The tops and roots were weighed separately and the roots were then passed through a parallel bar grader and separated into various sizes. The number and fresh weight of roots size 0 to 3 was recorded. Grades were as follows: size $0(<3 / 4$ inches in diameter $)$, size $1(3 / 4$ to $<15 / 8$ inches in diameter), size 2 ( $15 / 8$ to $<21 / 2$ inches in diameter), size $3(>21 / 2$ inches in diameter). Only size 1 and size 2 roots were considered marketable in this study.

Statistical analysis. Data were analyzed using JMP software (release 7; SAS Institute, Cary, NC). Raw data were transformed to obtain normal distributions. A square root transformation was used on stand count and root count data. For fresh weights, a constant of 1.0 was added to the data and a log base 10 transformation 
was used. A multiple regression with standard least squares fitting was used. A multilevel model was constructed with harvest date, row width, population, and all interactions as fixed effects, and plot and plot $\times$ subplot as random effects. In 2006, block was also included as a fixed effect. In the final model, only significant effects were used. Because the 2007 design did not include all combinations of factors, it was analyzed as two subsets: 1) the 25 - and 35 -plants $/ \mathrm{ft}$ population at all row widths, and 2) all plant populations at the 18- and 20-inch row widths only. An analysis of the combined 2006 and 2007 (subset 1 only) data was also run to determine if there was a significant year effect. Student's $t$ tests were used to compute individual pairwise comparisons. Tukey's honestly significant differences test (HSD) was used to test all differences among the least squares means. Data from size 3 roots were skewed and thus, chi-square tests were used to analyze the data. Data were first grouped.

Greenhouse trials. Seedballs of 'Ruby Queen' (same seed lot used in 2006 field trial) were sown in sterile Cornell Mix (Boodley and Sheldrake, 1982) in wooden flats at 11,18 , and 26 seedballs/ft of row. There were three replicates of each treatment. The number of emerged seedlings was counted at 10,17 , and $24 \mathrm{~d}$ after planting.

Seedballs of 'Red Ace' and 'Ruby Queen' were planted in 4-inch-diameter pots containing natural field soil that had a history of beet production and soil-borne pathogens that cause wirestem disease. There were six fungicide-treated seed lots from two seed companies. A total of 5,10 , or 15 seedballs were planted in a single row at 0.5 -inch depth. There were four replicate pots per treatment that were placed in a greenhouse for $36 \mathrm{~d}$. The number of emerged seedlings and the incidence of wirestem were recorded. Data were analyzed with JMP software using regression analysis with standard least squares fitting. A square root transformation was used for percentage of seedlings with wirestem. Means were separated by HSD. Because variety and seed lot did not have a significant effect, only the combined data are presented.

\section{Results and discussion}

Precise stands of table beet plants are difficult to achieve because of the multigerm seedballs. Seeding rate must be calculated based on sprout count (number of seedlings/seedball). In addition, seedballs planted in the field produce fewer seedlings than in laboratory tests (Clark et al., 1967) and a field factor based on soil type and seed treatment must be used. A field factor of 0.8 was used in our calculation of seeding rate to achieve the target plant stand.

The actual plant stand counts were very close to target (Table 1 ). Despite irrigation in 2007, dry conditions delayed seedling emergence, and thus we waited until $20 \mathrm{~d}$ to perform the stand counts. All populations were significantly different from each other in both years.

There was high seedling mortality between emergence and the first harvest date (Table 1), but there was no significant stand loss thereafter in either year. The percentage of plant loss increased with seedling density, but higher seeding rates nevertheless produced more roots (Table 1). A similar "self-thinning" of beet seedlings over time was reported by Benjamin et al. (1985). However, in other experiments (Benjamin and Bell, 1985), the proportion of seedballs that produced plants was unaffected by the planting density or duration of growth. In contrast, Warne (1948) reported a greater number of plants at harvest compared with stand counts taken 4 weeks after planting, presumably because of additional (delayed) germination or because two seedlings growing together were counted as one earlier. There was, however, a reduction in the percentage of theoretical stand as in-row plant density increased.

To investigate the possible cause of seedling loss in our experiments with increased plant density, we grew seeds in the greenhouse in potting mix or field soil. The number of seedlings remained unchanged between 10 and $24 \mathrm{~d}$ after seeding when the seeds were grown in a sterile potting mix (data not shown). Thus, in sterile soil, germination and emergence were not inhibited by neighboring seedballs or seedlings. When beet seedballs were planted at different densities in soil collected from a beet field, the average number of seedlings/seedball remained constant for a given seed lot at $36 \mathrm{~d}$. However, the incidence of wirestem disease significantly increased with higher planting densities (Table 2). It is well documented that plants of several species grown in dense stands develop more severe disease symptoms (Burdon and Chilvers, 1982; Zentmyer and Bald, 1977). Wirestem in New York is caused primarily by Rhizoctonia solani; however, Pythium ultimum and Phoma betae also can cause wirestem symptoms (Abawi et al., 1986). Even though all of the seedballs used in our field and greenhouse trials were commercial lots treated with fungicides that have activity against these fungi, wirestem was observed in our field trials and may have been the cause of seedling loss, although we did not

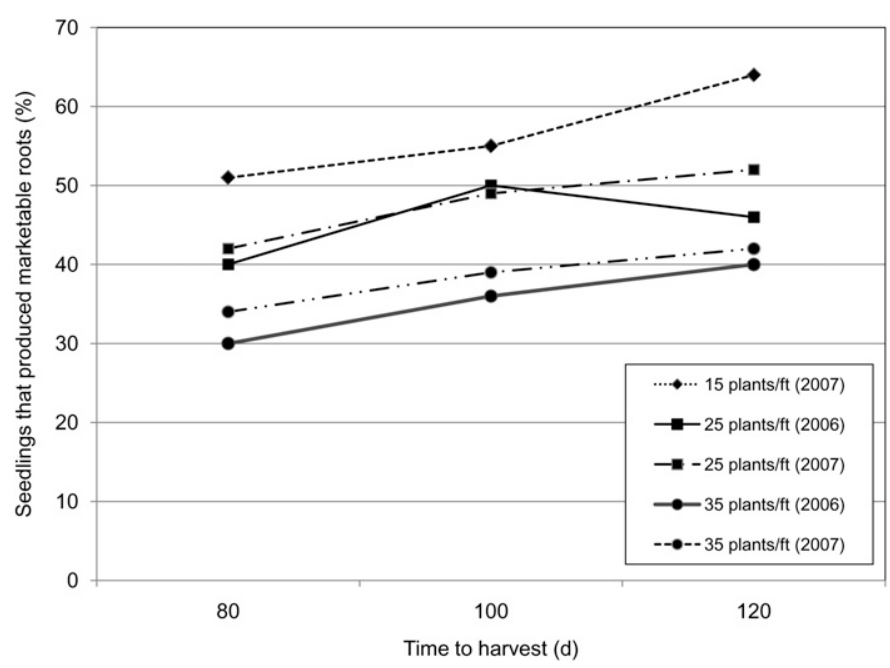

Fig. 2. The effect of in-row plant population and harvest date on the percentage of 'Ruby Queen' table beet seedlings that produced marketable roots $(3 / 4$ to $<21 / 2$ inches diameter $) ; 1$ inch $=2.54 \mathrm{~cm}, 1$ plant $/ \mathrm{ft}=3.2808$ plants $/ \mathrm{m}$. 
collect data on disease incidence or severity. The presence or absence of disease could be why Benjamin et al. (1985) reported self-thinning in one set of experiments, but not another (Benjamin and Bell, 1985).

Row width did not have a significant effect on the number of roots in the different size classes thus the data were combined. There were more undersize (size 0 ) roots with higher populations and fewer days to harvest (Fig. 1). The number of size 1 roots was significantly highest $(P<0.001)$ with the 35-plants/ft population. Harvest date did not have a significant effect on the number of size 1 roots. In contrast, the number of size 2 roots was greatest with 25 plants $/ \mathrm{ft}$ in $2006(P=0.0002)$ and $2007(P=$ $0.0101)$. When the 15 -plants $/ \mathrm{ft}$ data were compared with 25 and 35 plants/ft in the 18- and 20-inch row widths (2007), the difference between the populations was not significant $(P=0.49)$. Size 2 roots also increased with the number of days to harvest. As expected, more oversize (size 3 ) roots grew with lower plant populations and greater time to harvest. The highest percentage of seedlings that produced marketable roots was at 15 plants $/ \mathrm{ft}$, while the lowest was with the 35 -plants/ft population (Fig. 2). At lower in-row populations, there is less competition and more of the seedling roots can grow larger than $3 / 4$ inches in diameter. Lower plant populations also have a reduced risk of seedling die-off from pathogen infection.

Growers are paid based on the weight and grade of table beet roots, with size 1 being the most valuable. Harvest date (HD) and plant population $(\mathrm{P})$ was highly significant for size 1 and size 2 roots (Table 3 ). Row width (RW) did not have a significant effect. The fresh weight of size 1 roots was greater at 100 and $120 \mathrm{~d}$ compared with $80 \mathrm{~d}$ and at 35 plants $/ \mathrm{ft}$ compared with 25 plants/ft. There was a significant $\mathrm{HD} \times \mathrm{P}$ effect in 2006 because at $120 \mathrm{~d}$, the fresh weight of size 1 roots was lower than at 80 or $100 \mathrm{~d}$, whereas for 35 plants / $\mathrm{ft}$, the fresh weight increased linearly with days to harvest (data not shown). It may be that in 2006, a year with ample soil moisture, more roots were able to grow to size 2 by $120 \mathrm{~d}$. The interaction of $\mathrm{HD} \times \mathrm{RW}$ was also significant in 2007 and the combined

Table 3. Effect of harvest date, plant population, row width, and year on the fresh weight of size $1(3 / 4 \text { to }<15 / 8 \text { inches diameter })^{\mathrm{z}}$ and size $2(15 / 8$ to $<21 / 2$ inches diameter) 'Ruby Queen' table beet roots.

\begin{tabular}{|c|c|c|c|c|}
\hline \multirow[b]{2}{*}{ Root grade } & \multirow[b]{2}{*}{ Main effects } & \multicolumn{3}{|c|}{ Fresh wt $(\mathrm{kg} / 2 \text { ft row })^{\mathrm{y}}$} \\
\hline & & 2006 & 2007 & $2006+2007$ \\
\hline \multirow[t]{20}{*}{ Size 1} & Harvest date (HD) & & & \\
\hline & $80 \mathrm{~d}$ & $0.54 b^{x}$ & $0.44 \mathrm{~b}$ & $0.49 \mathrm{~b}$ \\
\hline & $100 \mathrm{~d}$ & $0.61 \mathrm{a}$ & $0.50 \mathrm{ab}$ & $0.55 \mathrm{a}$ \\
\hline & $120 \mathrm{~d}$ & $0.58 \mathrm{ab}$ & $0.53 \mathrm{a}$ & $0.55 \mathrm{a}$ \\
\hline & Significance & * & ** & ** \\
\hline & Population $(\mathrm{P})$ & & & \\
\hline & 25 plants $/ \mathrm{ft}^{\mathrm{w}}$ & 0.52 & 0.44 & 0.48 \\
\hline & 35 plants $/ \mathrm{ft}$ & 0.63 & 0.54 & 0.58 \\
\hline & Significance & ** & ** & ** \\
\hline & Row width (RW) & & & \\
\hline & 18 inches $^{\mathrm{z}}$ & 0.54 & 0.49 & 0.51 \\
\hline & 20 inches & 0.60 & 0.47 & 0.53 \\
\hline & 22 inches & 0.56 & 0.44 & 0.50 \\
\hline & 24 inches & 0.59 & 0.57 & 0.58 \\
\hline & Significance & NS & NS & NS \\
\hline & Year & - & - & * \\
\hline & $\mathrm{HD} \times \mathrm{P}$ & ** & NS & * \\
\hline & $\mathrm{HD} \times \mathrm{RW}$ & NS & * & * \\
\hline & $\mathrm{P} \times \mathrm{RW}$ & NS & NS & NS \\
\hline & $\mathrm{HD} \times \mathrm{P} \times \mathrm{RW}$ & NS & NS & NS \\
\hline \multirow[t]{20}{*}{ Size 2} & Harvest date (HD) & & & \\
\hline & $80 \mathrm{~d}$ & $0.45 \mathrm{c}$ & $0.43 \mathrm{c}$ & $0.43 \mathrm{c}$ \\
\hline & $100 \mathrm{~d}$ & $1.02 \mathrm{~b}$ & $0.72 \mathrm{~b}$ & $0.87 \mathrm{~b}$ \\
\hline & $120 \mathrm{~d}$ & $1.18 \mathrm{a}$ & $0.87 \mathrm{a}$ & $1.02 \mathrm{a}$ \\
\hline & Significance & ** & ** & ** \\
\hline & Population $(\mathrm{P})$ & & & \\
\hline & 25 plants $/ \mathrm{ft}$ & 1.00 & 0.78 & 0.88 \\
\hline & 35 plants $/ \mathrm{ft}$ & 0.76 & 0.57 & 0.66 \\
\hline & Significance & ** & ** & ** \\
\hline & Row width (RW) & & & \\
\hline & 18 inches & $0.74 \mathrm{~b}$ & $0.64 \mathrm{a}$ & $0.69 \mathrm{a}$ \\
\hline & 20 inches & $0.92 \mathrm{ab}$ & $0.70 \mathrm{a}$ & $0.79 \mathrm{a}$ \\
\hline & 22 inches & $0.84 \mathrm{ab}$ & $0.81 \mathrm{a}$ & $0.82 \mathrm{a}$ \\
\hline & 24 inches & $1.04 \mathrm{a}$ & $0.54 \mathrm{a}$ & $0.79 \mathrm{a}$ \\
\hline & Significance & * & NS & NS \\
\hline & Year & - & - & NS \\
\hline & $\mathrm{HD} \times \mathrm{P}$ & NS & NS & NS \\
\hline & $\mathrm{HD} \times \mathrm{RW}$ & NS & NS & NS \\
\hline & $\mathrm{P} \times \mathrm{RW}$ & NS & NS & NS \\
\hline & $\mathrm{HD} \times \mathrm{P} \times \mathrm{RW}$ & NS & NS & NS \\
\hline
\end{tabular}

${ }^{\mathrm{z}} 1$ inch $=2.54 \mathrm{~cm}$.

${ }^{\mathrm{y}} 1 \mathrm{~kg} / 2 \mathrm{ft}=1.1023 \mathrm{lb} / \mathrm{ft}=1.6404 \mathrm{~kg} \cdot \mathrm{m}^{-1}$

${ }^{x}$ Means within the same treatment that are followed by the same letter are not significantly different at $P=0.05$ as determined by Student's $t$ tests or Tukey's honestly significant differences tests. NS, * ${ }^{* *}$ Not significant or significant at $P \leq 0.05$ or 0.01 , respectively.

${ }^{w} \mathrm{l}$ plant $/ \mathrm{ft}=3.2808$ plants $/ \mathrm{m}$.

data. This interaction is not easily explained because the fresh weight of size 1 roots increased with time only for the 18-and 24-inch row widths (Fig. 3). There was no significant interaction between $\mathrm{HD} \times \mathrm{RW}$ in 2006. The fresh weight of size 1 roots was significantly higher in 2006 than 2007 , likely because of the difference in moisture between the years. The fresh weight of size 2 roots increased with days to harvest and was consistently higher at 25 plants/ft compared with the 35-plants/ft population. Year was not significant, nor were there any significant interactions. 


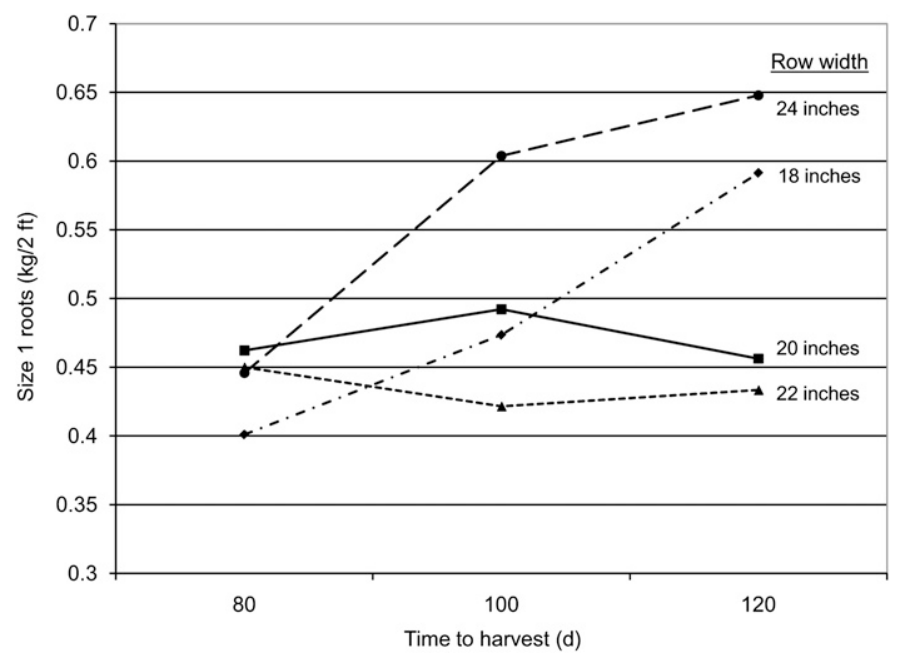

Fig. 3. The interaction of row width and harvest date on the fresh weight of size $1(3 / 4$ to $<15 / 8$ inches diameter) 'Ruby Queen' table beet roots in 2007; 1 inch $=2.54 \mathrm{~cm}, 1 \mathrm{~kg} / 2 \mathrm{ft}=1.1023 \mathrm{lb} / \mathrm{ft}=1.6404 \mathrm{~kg} \cdot \mathrm{m}^{-1}$

Table 4. Effect of harvest date, plant population, row width, and year on the marketable yield of 'Ruby Queen' table beet roots expressed as fresh weight $/ 2 \mathrm{ft}(0.61 \mathrm{~m})$ of row.

\begin{tabular}{|c|c|c|c|}
\hline \multirow[b]{2}{*}{ Main effects } & \multicolumn{3}{|c|}{ Marketable yield [fresh wt $(\mathrm{kg} / 2 \mathrm{ft}$ row $)]^{\mathrm{z}}$} \\
\hline & 2006 & 2007 & $2006+2007$ \\
\hline \multicolumn{4}{|l|}{ Harvest date (HD) } \\
\hline $80 \mathrm{~d}$ & $0.99 \mathrm{c}^{\mathrm{y}}$ & $0.87 \mathrm{c}$ & $0.93 \mathrm{c}$ \\
\hline $100 \mathrm{~d}$ & $1.63 \mathrm{~b}$ & $1.22 \mathrm{~b}$ & $1.42 \mathrm{~b}$ \\
\hline $120 \mathrm{~d}$ & $1.75 \mathrm{a}$ & $1.39 \mathrm{a}$ & $1.57 \mathrm{a}$ \\
\hline Significance & ** & ** & ** \\
\hline \multicolumn{4}{|l|}{ Population $(\mathrm{P})$} \\
\hline 25 plants $/ \mathrm{ft}^{\mathrm{x}}$ & 1.52 & 1.23 & 1.37 \\
\hline 35 plants $/ \mathrm{ft}$ & 1.39 & 1.10 & 1.24 \\
\hline Significance & ** & NS & ** \\
\hline \multicolumn{4}{|l|}{ Row width (RW) } \\
\hline 18 inches $^{x}$ & 1.28 & 1.12 & 1.20 \\
\hline 20 inches & 1.52 & 1.17 & 1.34 \\
\hline 22 inches & 1.40 & 1.25 & 1.32 \\
\hline 24 inches & 1.63 & 1.10 & 1.36 \\
\hline Significance & NS & NS & NS \\
\hline Yr & - & - & ** \\
\hline $\mathrm{HD} \times \mathrm{P}$ & NS & NS & NS \\
\hline $\mathrm{HD} \times \mathrm{RW}$ & NS & ** & ** \\
\hline $\mathrm{P} \times \mathrm{RW}$ & NS & NS & NS \\
\hline $\mathrm{HD} \times \mathrm{P} \times \mathrm{RW}$ & NS & NS & NS \\
\hline
\end{tabular}

${ }^{2}$ Marketable yield is the total of beet roots $3 / 4$ to $<2 \mathrm{l} / 2$ inches ${ }^{\mathrm{x}}$ in diameter; $\mathrm{l} \mathrm{kg} / 2 \mathrm{ft}=1.1023 \mathrm{lb} / \mathrm{ft}=1.6404$ $\mathrm{kg} \cdot \mathrm{m}-\mathrm{l}$.

'Means within the same treatment that are followed by the same letter are not significantly different at $P=0.05$ as determined by Student's $t$ tests or Tukey's honestly significant differences tests; NS, ${ }^{*},{ }^{*}$ Not significant or significant at $P \leq 0.05$ or 0.01 , respectively.

${ }^{\times} 1$ plant $/ \mathrm{ft}=3.2808$ plants $/ \mathrm{m}, 1$ inch $=2.54 \mathrm{~cm}$

In 2007 , a third treatment of 15 plants/ft was added for the 18- and 20 -inch row widths to test the hypothesis that plants could be more widely spaced in-row if the row widths were narrower. We reject this hypothesis because greater in-row spacing resulted in more oversize roots (Fig.
1). At 15 plants $/ \mathrm{ft}$, the fresh weight of size 1 roots was less than 35 plants $/ \mathrm{ft}$, and was statistically the same as 25 plants/ft (means were $0.18,0.15$, 0.11 for 35,25 , and 15 plants $/ \mathrm{ft}$ respectively; $P=0.0012$ ). There was no effect of population on the fresh weight of size 2 roots in this data set.
Marketable yield was examined on a per unit of row basis (Table 4) and a per acre basis (Table 5 ) because there are more rows per acre as the row width decreases, which could affect the results of the analysis of tons/acre. However, the trends were nearly identical with both analyses. Yield increased significantly with days to harvest (Table 4 and 5). The 25plants/ft population produced higher yields compared with 35 plants $/ \mathrm{ft}$, but this was significant only in 2006 and the combined $2006+2007$ data. Based on the data in Table 3, one would expect higher marketable yields with the 25-plants/ft population because there were more size 2 roots that were heavier than size 1 roots. In 2007 , there was no effect of population when 15,25 , or 35 plants $/ \mathrm{ft}$ were compared and this may also have been because there was no significant difference in the number of size 2 roots in these treatments. Row width had no effect on marketable yield $/ 2 \mathrm{ft}$ of row or marketable yield per acre. However, there was a significant HD $\times$ RW interaction in 2007 and a general trend of higher tons per acre with narrower rows (Fig. 4). Because row width did not have an effect on the marketable yield per foot of row, the higher marketable yield per acre with narrower rows is simply explained by the fact that there are more linear feet of row per acre as row width decreases. Although the plots were irrigated in 2007, dry conditions still impacted yield.

Our results are in agreement with Benjamin et al. (1985) that row width had little or no effect on the number and fresh weight of beet roots in different size classes. However, we did not test widths less than 18 inches given current commercial production constraints. In 2006, the fresh weight of size 2 beet roots was significantly lower in 18-inch rows compared with 24 -inch rows. However, there was no difference in 2007. In-row population density and harvest date had significant effects on the number of roots in the different size classes, as previously reported (Benjamin et al., 1985; Mack, 1968, 1979; Peck and Wilczynski, 1967; Tyler et al., 1982). As the in-row population increased, fewer roots grew to marketable size. Similarly, there was a greater proportion of undersize and small roots with fewer days to harvest. Our results 
Table 5. Effect of harvest date, plant population, row width, and year on the marketable yield of 'Ruby Queen' table beet roots expressed in tons/acre.

\begin{tabular}{|c|c|c|c|}
\hline \multirow[b]{2}{*}{ Main effects } & \multicolumn{3}{|c|}{ Marketable yield [fresh wt (tons/acre) $]^{\mathrm{z}}$} \\
\hline & 2006 & 2007 & $2006+2007$ \\
\hline \multicolumn{4}{|c|}{ Harvest date (HD) } \\
\hline $80 \mathrm{~d}$ & $13.6 b^{y}$ & $12.1 \mathrm{c}$ & $12.8 \mathrm{c}$ \\
\hline $100 \mathrm{~d}$ & $22.5 \mathrm{a}$ & $16.9 \mathrm{~b}$ & $19.7 \mathrm{~b}$ \\
\hline $120 \mathrm{~d}$ & $24.2 \mathrm{a}$ & $19.4 \mathrm{a}$ & $21.8 \mathrm{a}$ \\
\hline Significance & ** & ** & ** \\
\hline \multicolumn{4}{|l|}{ Population (P) } \\
\hline 25 plants $/ \mathrm{ft}^{\mathrm{x}}$ & 21.0 & 16.9 & 19.0 \\
\hline 35 plants $/ \mathrm{ft}$ & 19.2 & 15.3 & 17.2 \\
\hline Significance & ** & NS & ** \\
\hline \multicolumn{4}{|l|}{ Row width (RW) } \\
\hline 18 inches $^{\mathrm{x}}$ & 20.5 & 18.0 & 19.3 \\
\hline 20 inches & 21.9 & 16.9 & 19.4 \\
\hline 22 inches & 18.3 & 16.3 & 17.3 \\
\hline 24 inches & 19.5 & 13.3 & 16.4 \\
\hline Significance & NS & NS & NS \\
\hline $\mathrm{Yr}$ & - & - & ** \\
\hline $\mathrm{HD} \times \mathrm{P}$ & NS & NS & NS \\
\hline $\mathrm{HD} \times \mathrm{RW}$ & NS & ** & ** \\
\hline $\mathrm{P} \times \mathrm{RW}$ & NS & NS & NS \\
\hline $\mathrm{HD} \times \mathrm{P} \times \mathrm{RW}$ & NS & NS & NS \\
\hline
\end{tabular}

${ }^{\mathrm{z}}$ Marketable yield is the total of beet roots $3 / 4$ to $<2 \mathrm{l} / 2$ inches $^{\mathrm{x}}$ in diameter; $\mathrm{l}$ ton $/ \mathrm{acre}=2.2427 \mathrm{Mg} \cdot \mathrm{ha}^{-1}$ 'Means within the same treatment that are followed by the same letter are not significantly different at $P=0.05$ as determined by Student's $t$ tests or Tukey's honestly significant differences tests. NS, ${ }^{*},{ }^{*}$ Not significant or significant at $P \leq 0.05$ or 0.01 , respectively.

${ }^{\mathrm{x}} \mathrm{l}$ plant $/ \mathrm{ft}=3.2808$ plants $/ \mathrm{m}, \mathrm{l}$ inch $=2.54 \mathrm{~cm}$

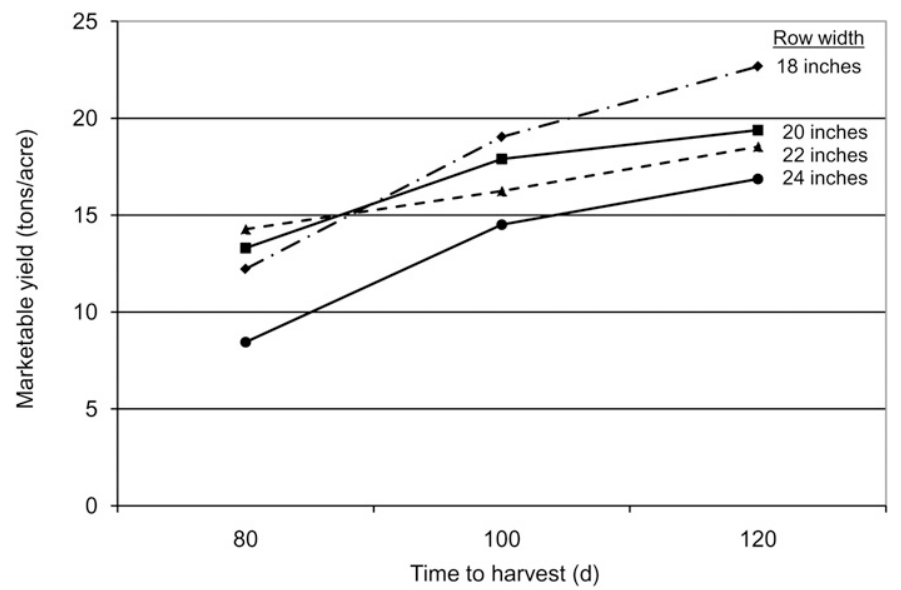

Fig. 4. The interaction of harvest date and row width on marketable yield of 'Ruby Queen' table beet roots in 2007. Data are combined for the 25- and 35-plants $/ \mathrm{ft}$ population data set; 1 plant $/ \mathrm{ft}=3.2808$ plants $/ \mathrm{m}, 1$ inch $=2.54 \mathrm{~cm}$, 1 ton $/$ acre $=2.2417 \mathrm{Mg} \cdot \mathrm{ha}^{-1}$.

agree with Peck and Wilczynski (1967), where the yield of size 1 roots remained nearly constant over the harvest period while the yield of size 2 and size 3 roots increased. As the crop grew, more size 1 roots moved into the larger classes, and were replaced by roots that were previously less than $3 / 4$ inch (Fig. 1).
The highest gross yield of marketable beet roots was obtained with 25 plants/ft and $120 \mathrm{~d}$ to harvest. A higher percentage of size 1 roots for whole "baby beet" packs was obtained at a higher plant density ( 35 plants $/ \mathrm{ft})$ and earlier harvest $(80 \mathrm{~d})$. However, higher seeding rates were generally not desirable due to higher seed costs and greater plant die-off. Reducing the row width to 18 inches did not affect the grade or marketable yield of the beet roots, and was less desirable due to increased risk for diseases such as pocket rot caused by $R$. solani and leaf spots caused by Cercospora beticola and P. betae (Shah and Stivers-Young, 2004). Tyler et al. (1982) reported that narrow rows are also more time consuming to harvest with a top-puller.

\section{Literature cited}

Abawi, G.S., D.C. Crosier, A.C. Cobb, and R.F. Becker. 1986. Root rot of table beets in New York State. New York's Food Life Sci. Bul. No. 115.

Benjamin, L.R. 1987. The relative importance of cluster size, sowing depth, time of seedling emergence and between-plant spacing on variation in plant size in red beet (Beta vulgaris L.) crops. J. Agr. Sci. Cambridge 108:221-230.

Benjamin, L.R. and N. Bell. 1985. The influence of seed type and plant density on variation in plant size of red beet (Beta vulgaris L.) crops. J. Agr. Sci. Cambridge 105:563-571.

Benjamin, L.R., R.A. Sutherland, and D. Senior. 1985. The influence of sowing rate and row spacing on the plant density and yield of red beet. J. Agr. Sci. Cambridge 104:615-624.

Boodley, J.W. and R. Sheldrake. 1982. Cornell peat-lite mixes for commercial plant growing. New York Agr. Expt. Sta. Agr. Info. Bul. 43.

Burdon, J.J. and G.A. Chilvers. 1982. Host density as a factor in plant disease ecology. Annu. Rev. Phytopathol. 20:143-166.

Clark, B.E., N.H. Peck, R.F. Becker, and D.B. Kline. 1967. Predicting field stands of table beets. New York State Agr. Expt. Sta., Cornell Univ., NY Seed Res. Circ. No. 2.

Goldman, I.L. and J.P. Navazio. 2008. Table beet, p. 219-238. In: J. Prohens and F. Nuez (eds.). Handbook of plant breeding, Vol. 1. Vegetables I. Springer, New York.

Hipp, B.W. 1977. Influence of nitrogen and length of growing season on yield and size distribution of table beets. J. Amer. Soc. Hort. Sci. 102:598-601.

Mack, H.J. 1968. Spacing affects yield, size of table beets. Oregon Veg. Dig. $17: 1-4$.

Mack, H.J. 1979. Effects of row spacings, fertilizers, and harvest dates on table 
beets. J. Amer. Soc. Hort. Sci. 104:717720 .

Peck, N.H. and H. Wilczynski. 1967. Narrow rows for table beets. New York State Agr. Expt. Sta. Farm Res. 33:6-7.

Shah, D.A. and L. Stivers-Young. 2004. Factors associated with decay in table beets identified by a statistical analysis of grower and processor records. HortTechnology 14:25-29.

Tyler, F.T., L. Adas, and L.R. Benjamin. 1982. Spacing red beet for high returns. Grower 97(25):19-23.
U.S. Department of Agriculture (USDA). 1998. United States standards for grades of canned beets, eighth issue. Federal Register 63 FR 36201, July 2, 1998, amended April 2003. I Mar. 2010. <http://www.ams.usda.gov/standards/ stanfrfv.htm>.

U.S. Department of Agriculture (USDA). 2009. 2007 Census of agriculture, released 4 Feb. 2009. I Mar. 2010. <http:// www.agcensus.usda.gov>.

Warne, L.G.G. 1948. Spacing experiments on vegetables IV. The yield of globe beet grown at twelve spacings and two manurial levels, in Cheshire. J. Hort. Sci. 26:296-303.

Warne, L.G.G. 1953. Effects of close spacing on the growth of garden beet. Nature 172:506.

Webster, A.B. 1969. Manuring and spacing experiments on vegetables. N.Z. J. Agr. Res. 12:381-416.

Zentmyer, G.A. and J.G. Bald. 1977. Management of the environment, $\mathrm{p}$. 121-144. In: J.G. Horsfall and E.B. Cowling (eds.). Plant disease, an advanced treatise, Vol. I. Academic Press, New York. 